\title{
CONCEPT OF NATIONAL-MORAL SELF-CONSCIOUSNESS IN EXAMPLES OF ARTISTIC IMAGES (IN THE CONTEXT OF CREATIVE ACTIVITY OF ALI ILIDIRIMOCHLU)
}

Summary. The aim of the article - is based on the analysis of the works of the famous Azerbaijani writer Ali Ildrimoglu, the problems of the concept of human being, the ideal person and the problem of sensuality, meeting the needs of human values.

Research methods: In the course of the study, cultural-historical and biographical methods were used to identify the concept of human being in the works of Ali Ildrimoglu, the environment of their heroes and socio-political events were evaluated through the prism of the writers' point of view. An important role in determining the concept of human life was played by the analysis of the environment and era of writers. Postmodern and psychoanalytic methods were also used to define the concept of human existence.

The use of formal logical methods (analysis, synthesis, induction, deduction, analogy) facilitated the study.

The novelty of the study lies in the fact that the author gives a free idea of the character, hero and literary essence of the personality-personality factor in the work of Ali Ildrimoglu. The idea of a perfect person in the writer's work is tuned to national-moral self-determination. This is mainly manifested in the light of the psychological characteristics and genetic memory of the heroes represented.

The author comes to such conclusions that the idea of national-moral self-determination is a field of study of aesthetic, artistic and other humanitarian fields. The role of national-moral self-determination in the formation of man in literary works and ways to solve this problem have always been in the spotlight.

It is noted that in the writer's creative activities, the ideas of constructing images of heroes and personality formation are dynamic. National-moral attitudes of A. Ildirimoglu, who lived in political and ideological, literary and aesthetic situations of different eras in the XX and XXI centuries, improved and developed over time and became the embodiment of monumental characters with perfect national ideas about the fate of the nation. From this point of view, the works of Ali Ildirimoglu play an exceptional role. As a writer, he could accomplish this task at the highest level in the name of his heroes. It is noted that the characters in the works of Ali Ildirimoglu should be carefully studied in the future.

Key words: hero, perfect human being, typical Azerbaijani character, self-determination, subjectivity, moral values.

Introduction. The distinguished representative of Azerbaijani literature, Ali Ildirimoghlu has a unique place in the history of literary prose. His creative activity combines political-moral and ideological realities of $20^{\text {th }}$ and $21^{\text {st }}$ centuries. Ali Ildirimoghlu was well aware of the political, social, cultural, ideological realities of the period of his life. He has always been in search of new methods and forms to depict the national realities of the epoch of his life.
He always tried to create the ideas of national self-determination and used different literary ways for the realization of these ideas. He was perfectly aware of historical-cultural potential of Azerbaijani person and tried to depict of national values of Azerbaijanis in his works. He has always been attached to national-moral values and the characters he has created in his works have been inspired by the moral world of his nation. The ideas of national-moral self determination can be seen in all his works throughout of his creative activity. His human being concept is based on this moral aesthetic source.

The aim of the article is based on the analysis of the works of the famous Azerbaijani writer Ali Ildrimoglu, the problems of the concept of human being, the ideal person and the problem of sensuality, meeting the needs of human values.

Research methods: In the course of the study, culturalhistorical and biographical methods were used to identify the concept of human being in the works of Ali Ildrimoglu, the environment of their heroes and socio-political events were evaluated through the prism of the writers' point of view. An important role in determining the concept of human life was played by the analysis of the environment and era of writers. Postmodern and psychoanalytic methods were also used to define the concept of human existence.

The use of formal logical methods (analysis, synthesis, induction, deduction, analogy) facilitated the study.

The novelty of the study lies in the fact that the author gives a free idea of the character, hero and literary essence of the personality-personality factor in the work of Ali Ildrimoglu. The idea of a perfect person in the writer's work is tuned to national-moral self-determination. This is mainly manifested in the light of the psychological characteristics and genetic memory of the heroes represented.

Being tied up with the language, religion, customs and traditions, moral-cultural behaviour is closely connected with the gene and heritage of nation. From this point of view respect to national-moral traditions is characteristic for Ali Ildirimoghlu as a personality, his moral world and his creative works. Despite living within the strict political realities Ali Ildirimoghlu's heros were faithful to their ideals, respected national-moral values, and lived in the spirit of love of motherland. All the human being values of his heros reflect the values of the author. Ali Ildirimoghlu is considered to be one of the main founders of national-moral selfdetermination ideas in Azerbaijani literature. His attempt to form a perfect personality is highly appreciated in Azerbaijani literature.

Statement of the main material. Subjectivised people, motherland: coded social-cultural feature of ethnos. 
The phenomena of human being and personality have always been one of the intellegence and force centers and the locomative of rapid development. Personalities make the history is also acceppted in researches of literature and theoretical - aesthetic thinking. This aesthetic, psychological and cultural trend is the main source of topic for literature. Creating a hero and forming personality has always been one of the actual issues of literature and social sciences. This is closely connected with national-moral values of personality, who tries to immortolize mental features in his own image and transfer all positive elements of his people to future generation. Thus Ali Ildirimoghlu's heroes have always preserved dignity in their live experience and proved that they are perfect human beings and morally unique.

Ali Ildirimoghlu's heroes are honest, decent and faithful to their motherland. These heroes could inherit the memory, life style, moral and national values of Azerbaijani people which have been formed for thousands of years and pass to new generation. Who are they? They are those who honostly work hard in cornfields, sow, cut the grass in order to keep his body and soul together. It is Ildirim kishi who is wise, noble. It is brave, fighting, a man of his word and honest Nazim Ilham. It is Hirjat Jahangir, Sujaddin, Najaf, Mursud kishi, Qachaq Mursal, Amrah, "Kishi Tavat", Jabrayil, Qachaq Qabil Mirvlanverdi, Ibadulla and others. These characters are decent people of their motherland who combine honesty, bravity, faithfulness and all moral values. Individuals can combine positive moral values of the whole people.

Individualization, first of all demands the formation of the psychology, character and morality of human being. It is clear that moral values are very important for surviving, because

The principles of fundamental individualization is closely connected with moral values of the psychology of human being [5, p. 240]. Ali Ildirimoghlu sees his heroes having high morals and being completely honest. He puts his heroes to test by fair unwritten laws.

The writer's positive characters are not always ideal. As any human being they also have contrasts and strange feelings. But as far as the interest of motherland is concerned, high moral values of his heroes prevail. Good man is a man who has good human being values. Ali Ildirimoghlu's human being values, his social position, personality is closely connected with national-moral self-determination and these features are demonstrated in his creative activity. He depicts all these above mentioned features in his all works. Garay Fazli is completely right to emphasize Ali Ildirimoghlu's fundamental missions in writer's short stories. " $<\ldots>$ Modernism in his works goes beyond the boundaries of time and covers all periods of time, as far as dignity, honesty, fighting for ideals is concerned. The great achievement of the writer is connected with his ability that he could develop such vast concept in his short stories and essays. From this point of view his "The position like a King", "Honest Man", "Favour" and "Honest" short stories should be highly appreciated" [7, p. 11].

Embodiment of writer's personality in his heroes. Ali Ildirimoghlu seriously approaches the process of formation of personality and demonstrates matchless ability and talent in depicting the charecteristic features of his heroes, and at the same time can skillfully transfer his own characteristic features to his heroes. Ali Ildirimoghlu in his novel "Journalist Forced" highlights the characteristic features and lives of personalities, disputes about the role of personalities in the development and perfection of society. Professor Aliheydar Hashimov writes about the main goal of writer in this novel: "Ali Ildirimoghlu is a real prototype and live sample of positive characters who are matchless in their behaviour in society, being patient, honest, never losing confidence in hard times, being indifferent to fame, not being tired of fighting for justice" [9, p. 71]. The main hero of the novel "Journalist Forced" Nazim Ilham with all his spiritual-moral characteristic features is Ali Ildirimoghlu himself.

The writer in the presentation of his heroes uses ethnospective, ethno genetic and ethno linguistic methods. His heroes are unique, they are completely faithful to their national, mental and moral values. The writer's such approach influences on the meaning and content his multispectiral creative activity. The writer's typical heroes are perfect personalities in society, living with saint social and positive style of norms of nation they belong to. They reflect characteristic features of their ancesters and by their behaviour, language, and culture can be sample for others. The hero of "Zoren Journalist" Nazim Ilham is young, energetic, talented and courageous journalist. The novel depicts the Soviet period of Azerbaijan. This period was full of contradictions, and to prove himself as a personality was very difficult. Nazim Ilham has two arms: first, his modern scientific-intellectual level, his education, second his talent, moral, based on national mental values. These two parameters form his perfect and courageous personality. The second feature, of course, is formed by one of the ethnogenetic factors. Ali Ildirimoghlu characterizes his hero's life, creative activity, social thinking, belief and struggle by ethnogenetic factors.

While living in the soviet period, Nazim Ilham managed to take a stand against misdeeds of public life, never reconciling morally with the voluntary policy and static, cliché decisions of the Soviet government and Communist Party that were contrary to human mind, will and spirit and was in continuous struggle against these scholastic codes with his pen and personality. The writer links this phenomenon with moral connection to national values. In this context, the writer made frequent tours of Nazim Ilham's genealogy and constantly remembers his ancestors' lifestyle and culture of thinking. Thus, he emphasizes the healthy roots of the hero. This in turn provides a stimulus for him to create an image of a perfect, modern personality, who is loyal to national values.

In the recent years there has been a growing interest in the scientific and literary literature in the problem of personality. This is not accidental and is related to some issues. After the collapse of the Soviet Union, the independent states established in its territory, including our country transitioned to an open society. At this time, the lifestyle and outlook of people were seriously changed, and favorable conditions were created for realization of one's own ideas and possibilities and demonstration of free thinking and creative activity. On the other hand, the evolution of the scientific and cultural picture of the world, as well as the large-scale globalization process played its important role in the formation of the modern personality. From this aspect, let us pay attention to the following citation: "The traditions, norms and values that are reflected in the behavior and inner world of a personality are components of culture. Individualization exists more or less in every culture. Therefore historical types of personality are viewed as carrier of major norms and values relevant to modern society in the cultural sphere" $[6$, p. 5].

The writer's characters in terms of world literature. The characters that Ali Ildirimoghlu brings to the literature with their 
individual sketches in fact contain the noble values of the nation and the most refined and precise moral qualities. These people carry various functions as literary characters and with all the parameters they are characteristic of the type of Azerbaijani human. From the point of view of monumentality and humanity, these heroes can be compared with the leading images of world literature. In this aspect, Doctor of Philology Gazanfar Kazimov's comments are interesting. He derives interesting conclusions from analogous comparisons between the main hero of the Mountains without Amrah novel, centurion Amrah and famous heroes of the world literature: "The centurion Amrah is fully developed as a character and hero. In the background of the life events, he leaves deep traces in memories as a living human being. It is possible to find parallels with several literary heroes and discover relevant features of the novel's main hero, Amrah the centurion's socio-political activities, personal qualities, life style and struggle. Fugitive Nabi, Fugitive Karam or Georgian writer J. Amirejibi's character named Data Duteshkhia, L. Tolstoy's Haji Murad are undoubtedly connected in certain ways. Each of these heroes struggles against the Evil and are fighters of the Good. Yet, Amrah is also individual as a literary hero. Without doubt, his activity and struggle are aimed against evil and oppression in the global sense. The individuality is that he protects his motherland and defends his own nation from the invading enemies" [8, p. 19].

Yes, the personal life of Amrah the Centurion thus attains the character of public duty and human mission, steps out from certain barriers and life style peculiarities, transforms into service to one's motherland and nation and ranks in the context of struggle against Armenian invaders.

Amongst the heroes created by Ali Ildirimoghlu, Ildirim is a character that is particularly noteworthy due to his own national-mental values (My farmworker father). Ildirim, who is an embodiment of cleanliness, purity, spiritual and moral values, can be compared to a large range of heroes in world literature. Ildirim is a pure and halal person. He doesn't bow down in front of anybody, nor does he force others to bow down in front of himself. He speaks the truth in a straightforward manner and does not refrain from anybody. With his simple farm life and simple livelihood, he helps everyone and extends his helpful hands to all. With the callosity in his hands and sweat on his forehead, he is proud and unbeatable. However, the most important feature characterizing Ildirim is his inner sensitivity, vigor and kind heart. In his soft heart, everybody has their own place. These features resemble he character of grandfather Momin in ChingizAytmatov's The dog running along the sea. Both eastern mentality and natural conditions, pure village psychology dominate in the qualities bringing these two heroes together.

Mostly moral ties connect these two characters - kindness, warmth,empathy.Also, at this point, themechanical and subconscious differences in the character projection of the characters emerge. Ildirim is fully free in his actions, feelings and senses, with his wilful actions and strength of will, he is responsible for himself. As to grandfather Momin, he is not just a person with all his inner purity, moral values and humanistic actions, but also a person who lives within this narrow frame of his character, as if he were a cosmetic figure managed from the outside. He is under the will of his son-in-law Orazgulu and while grandfather Momin wishes to live with his own deep inner world, Orazgul is an angel with wings burnt on the borders. Life transforms him into a weak flatterer, slave and servant. And, as the author writes: How could grandfather Momin dare to not be kind, Orazgul would beat him blue.
One of the most profound, rich and colorful characters of the writer, hero of The Fate novel, Stubborn Jahangir is by nature a brave man who doesn't give up his principles. In spite of all his deprivations, he does not abandon his purpose, goes through enormous difficulties, and is victorious at the last moment, thanks to his patience. The Stubborn Jahangir remains a generous human being in all cases, in every extreme situation, never forgets helping others while himself in need of a help and surprises everybody with his altruism. All of these qualities bring him closer to Jean Valjean, one of the mysterious and well-known heroes of world literature, the Les Misérables. With his hard life and fantastic destiny, the Stubborn Jahangir is also remembered as a mystical human being similar to Jean Valjean. In all parameters, these two look quite similar: life activities, adventures, penal servitude and exile to Siberia, kind treatment of others (without waiting for something in return), inner freedom and feelings of humane humanism. All of these bring both heroes to the same moral and spiritual coordinates. Their appearance is also quite similar - a strong body like steel, unstoppable arms, unbreakable will and enthusiastic spirit. In addition, Ali Ildirimoghlu's creative maneuvering, visual methods, thinking skills and the ability to create characters also remind of Victor Hugo's creative method. Sometimes the literary and artistic pathos, stylistics and figurative thinking of these two writers coincide. Mostly spiritual resemblance, creative kinship is felt between them, rather than aesthetic tendency in the teacherstudent relationships.

Azerbaijani woman as a carrier of national values. Preservation of moral values and their transmission to future generations play a special role in the creative activity of Ali Ildirimoghlu. As the symbols of national morality, beauty, tenderness and decency, they are typical Azerbaijani characters.

The characters of Basira (Journalist Forced) and Ganira (Fate) are the heroes developed by Ali Ildirimoghlu with the most sensual feelings and written with the most sacred feelings. True, they fail to find an opportunity to fall in love and be loved, live and end their ill-fated lives with unrequited feelings. Even if they are deprived of love in their lives, they find a sincere author's love and caring as literary characters. The writer describes his heroes with a pure pen. He decorates and enriches these ill-destined girls with tender feelings.

We face this ill-fated love story also in the novel The day the stones rained. In this piece, Greta has been described with great love and sincerity. With Armenian mother and Azerbaijani father, Greta is remembered as a person with higher values.

A. Ildirimoghlu is "greedy" and conservative in his attitude towards love. These features do not prevent him from raising the lower corners and the nucleus of sincere attitude towards love, which is a source of positive energy for human life.He fails to hide his sincere feelings about love, which in one way or another evokes a man's soul, develops as a body within body and is the primary source of evolution for human consciousness. Undoubtedly, the main hero of his love Odyssey is Raziyya, who from this point of view is a fully refined character covered in purity, sincerity, cleanliness and virginity.

Raziyya is self-sacrificing not only in her attitude towards her father, but in general, in her social position, in communication with people and is irrevocable, determined, and steadfast in the path of her love. The fact that she accidentally meets Nazim Ilham in a Moscow hospital, donates one of her kidneys to him 
without Nazim Ilham's knowledge (as the author writes, "the limb Raziyya entrusted him"), enters into conflict with her relatives at the end of the novel, who wish to arrange a forced marriage for her, remains faithful to her first love and commits suicide at the last moment says everything about the braveness, determination and moral superiority of this girl. The writer is the impresario of exactly such kind of Azerbaijani women. At this point, it would be relevant to compare Raziyya with female heroes of Nizami Ganjavi, in particular Shirin and draw parallels between them. Shirin passes all sociopolitical turmoil and remains faithful to Khosrow and commits suicide at the last moment, over Khosrow's corpse. "Despite all her weaknesses and sufferings stemming from love, the death of Shirin, who never abandons her principle of honor in life, is also with honor. Nizami says the following about Shirin, who commits suicide after murder of her husband Khosrow: "Nobody has killed themselves for another person in this world except for Shirin"'".

There is no shortage of women who cannot tolerate murder of their husbands and die. Yet, Shirin has a special right: nobody has died for someone else with such beauty. She visits her husband's grave not as an elderly woman to reduce her pain and cry, but as a happy bride wishing to join her lover and never again leaves this "bridal room" [10, p. 170].

All of these provide a basis for a certain analogy between Raziyya and Shirin.Shirin and Raziyya are at the same point, one before her husband Khosrow, while the other before her ill-fated lover Nazim Ilham. This point is raised to the level of sainthood particularly at the end of the Zoran journalist novel.

The heroes created by him are warriors to the end, and they are the people who testify to their identity in the context of these selfless exchanges. Unfortunately, it's hard to say these words about his female characters. We have noted that they carry the feminine beauty and elegance in their images with dignity. They are internally free people, women who are self-respecting and who hold their dignity and honor above all else. Yet, they fail to fight for their rights and social statuses till the very end. At the last moment, honor and self-esteem, the modesty syndrome cost them their lives as a passive substance. Ganira (Fate) and Raziyya (Journalist Forced) commit suicide, while Basira (Journalist Forced) die in the vortex of morality and honor. True, the writer's logic manages to convince the reader in all of these endings, but in any case, the reader feels regret and frustration, which is by no means temporary.

Amongst the female heroes of the writer Tavat the Man or Sword Tawat is one of the most interesting ones. After the Armenian vandals murder her brothers, Tawat takes off her female garments, dresses as a man and swears to fight till her last drop of blood and revenge her brothers. She fulfills her promise. Day and night, she chooses mountains and forests as her abode and at every chance fights the Armenians bravely and becomes their nightmare. We know this interesting personality more closely from the writer's novel titled Incandescent lines. The character of Tawat the Man, whose rich and interesting life does not fit into a single novel, is unfortunately described on the surface, episodically. Yet, as a writer, Ali Ildirimoghlu has enough lexical abilities, literary and semantic units, but also the chronotopical memory required for presentation of such characters in a wider specter.

The writer is both a chronicler and a barometer of his own time period. Not only the pulse of life, but also his own pulse beats in all of his words and expressions and his identity is engraved in between his lines. Thus, the writer elevates also to the status of a critic, advisor and wise old guide of his own timeline. These qualities have a special range in a sensitive writer like Ali Ildirimoghlu. In this sense, the writer's presentation of his own personality in the person of his heroes is fully acceptable and understandable. He has always remained faithful to these principles: to create oneself while writing, to reflect his own personal features in the person of his characters and to transfer his own personality to his favorite positive heroes.

Conclusions. The idea of a perfect man and whole personality is an artistic aesthetic line that covers all the poetic structural levels of A. Ildirimoghlu's creativity (content, form, plot, motif, language, style, etc.). This line connects to the artist's world of faith, his sense of cognitive and aesthetic perception. This in turn reflects mainly in the image of his heroes. Being one of the people and perceived the spirit of the nation as the national essence of his existence, throughout his life and creative activity A. Ildirimoghlu has not been left out of the nation, his nation, its national existence and interests. His characters, heroes living with these ideas and thoughts are remembered for their mental characteristics as the carrier and support of the writer's ideals. Embedded in all national ideology and spirit, A. Ildirimoghlu has always tried to realize national-moral self-perception in one form or another in his creative work, which coincided with the Soviet epoch and independence period. His fully-armed national-moral characters and personalities reflect the realities of Azerbaijan and its national memory in all of theiraspects. Rigidly opposed to the true manifestations of nationalism, the ideological fetters of Soviet literature have pushed the writer to search for new content, form and heroes in pursuit of national-moral self-perception ideas. As a result, the A. Ildirimoghlu signature has become a stable promoter of national values in the space of Azerbaijani literary thinking.

In the artist's creative activity, the ideas of hero-building and identity-building are dynamic. The national-moral meetings of A. Ildirimoghlu, who lived in the political and ideological, literary-aesthetic spirits of the various epochs in the $20^{\text {th }}$ and $21^{\text {st }}$ centuries, have improved and developed over time and have become the embodiment of monumental characters with perfect national ideas about the nation's destiny.

Research shows that human conception is the main characteristics of social phenomena and is the source and nucleus of social activity. In the modern world, the progress of human mind and spirit, the preservation, salvation and development of national cultures and values are among the main factors contributing to the rise of the universal culture. The human factor, taken as a social, moral, spiritual and psychological issue, as well as self-perception takes a special place in the fundamental principle of artistic thinking as a substance that requires continuous expansion of the possibilities needed for the fuller development of life. Consequently, discussions of self-perception intend constant improvement of the economic, political and spiritual life of the nation while refining the spiritual and psychological environment surrounding human beings. Its reflection in scientific literature and fiction gains a conceptual nature as a serious and important issue. From this point of view, analysis shows that the work of A. Ildirimoghlu's creative activity is not a local creative invoice reflecting the human factor and concept of identity, but rather a significant human artistic phenomenon that can well be a subject of conceptual analysis. 


\section{References:}

1. Aristotle. Poetics. Baku : Azerbaijani State Publishing House, 1974. P. 192 (in azerb.).

2. Azerbaijani ethnography. V. I. Baku : Elm, 1988. P. 456 (in azerb.).

3. Azerbaijani ethnography. V. II. Baku : Sharg-Qarb, 2007. P. 384 (in azerb.).

4. History of Azerbaijani literary language (Soviet period). V. III. Baku : Elm, 1982. P. 253 (in azerb.)

5. Dadayev Sh. Psychology. Baku : Ganun, 2017. P. 456 (in azerb.).

6. Afandiyev M., Majidgizi S. Personality-culture system. Baku : Elm, 2008. P. 386 (in azerb.).

7. Ildirimoghlu A. Grief. Baku : Ganjlik, 1993. P. 272 (in azerb.).

8. Ildirimoghlu A. Selected pieces. Vol. XI. Baku : Science and Education Publishing-Printing Enterprise, 2017. P. 323 (in azerb.).

9. Ildirimoghlu A. The echo of lines. Baku : Aspoliqraf, 2011. P. 480 (in azerb.).

10. Rasulzadeh M. Azerbaijani poet Nizami. Translation from Turkish : Professor Rustam Aliyev. Baku : Azerneshr, 1991. P .232 (in azerb.).

Алісв Л. Концепція національно-моральної самосвідомості у прикладах художніх образів (у контексті творчої діяльності Алі Ільдірімоглу)

Анотація. Мета статті - на основі проведеного аналізу робіт відомого азербайджанського письменника Алі Ільдірімоглу дослідити проблеми концепції людського буття, ідеальної людини, проблеми чуттєвості, задоволення потреб, людських цінностей.

Методи дослідження: у процесі дослідження для виявлення концепції людського буття в працях Алі Ільдірімоглу були використані культурно-історичні та біографічні методи, проведено оцінювання середовища, оточення героїв творів і соціально-політичних подій крізь призму погляду письменників. Важливу роль у визначенні концепції людського буття відіграв аналіз середовища й епохи письменника. Для визначення концепції людського буття також використано постмодерністський і психоаналітичний методи.

Використання формальних логічних методів (аналіз, синтез, індукція, дедукція, аналогія) полегшило дослідження.

Новизна дослідження полягає в тому, що автор висвітлює уявлення про характер, героїв і літературну суть особистісного чинника у творчості Алі Ільдірімоглу. Ідея досконалої людини у творчості письменника грунтується на національно-моральному самовизначенні. Це в основному проявляється у психологічних характеристиках і генетичній пам'яті представлених героїв.

Автор доходить висновку, що ідея національно-морального самовизначення є областю дослідження естетичної, художньої та інших гуманітарних галузей. Роль національно-морального самовизначення у формуванні людини в літературних творах і шляхи вирішення цієї проблеми завжди були в центрі уваги.

Зазначається, що у творчій діяльності письменника ідеї побудови образів героїв і формування особистості $\epsilon$ динамічними. Національно-моральні настанови А. Ілдірімоглу, який жив у політичних, ідеологічних, літературно-естетичних ситуаціях різних епох у XX і XXI століттях, iз часом удосконалювалися, розвивалися, втілені в монументальних персонажах із досконалими національними уявленнями про долю нації. Із цього погляду твори Алі Ільдірімоглу мають виняткове значення. Як письменник він міг виконати це завдання на вищому рівні в ім'я своїх героїв. Зазначається, що герої творів Алі Ільдірімоглу мають ретельно бути вивченими в майбутньому.

Ключові слова: герой, досконала людина, типовий азербайджанський характер, самовизначення, суб'єктивність, моральні цінності. 